\title{
TURN-TAKING IN CINEMATIC DISCOURSE: LINGUISTIC CHARACTERISTICS AND PRACTICAL IMPLICATIONS FOR ESP TEACHING
}

\author{
Iryna Lavrinenko \\ V. N. Karazin Kharkiv National University, Kharkiv, Ukraine \\ irina.lavrinenko@karazin.ua \\ Iryna Shevchenko \\ V. N. Karazin Kharkiv National University, Kharkiv, Ukraine \\ iryna.shevchenko@karazin.ua
}

\begin{abstract}
The article focuses on the issues of teaching turn-taking for ESP students in blended distance learning courses at B2 level. It lays the rationale for the use of film episodes of business interaction in distance learning highlighting turn-taking as an operational metadiscursive category. In multimodal cinematic discourse, turn-taking is performed by heterogeneous semiotic resources: linguistic, non-linguistic, cinematic codes and underpinned by intersubjectivity. Turn-taking strategies of initiating and responding types are viewed as a system of interactional dialogic communication management which includes discursive means of turn-claiming, attemptsuppressing and turn-yielding where each type is actualised by its own set of tactics and techniques. We claim that ESP learners need to know the main parameters for turn-taking in oral professional communication; such as the participants' stance, speaker - hearer relations and their intersubjectivity, the transition point in a conversation, discourse situations, and specific semiotic resources. In cooperative discourse situations, turn-claiming and turn-yielding strategies are determined by initiating tactics of statement or interrogation. Unlike this, in conflict situations, turn-taking strategies depend upon initiating tactics of statement, interrogation, order, inducement and predetermine responding tactics. In asynchronous and blended formats of distance learning, the preferable delivery methods for this material include video recordings and digital games which facilitate receiving new information and motivate students to practice new communicative skills.
\end{abstract}

Keywords: ESP; distance learning; communicative competence; turn-taking, strategy; intersubjectivity; cinematic discourse; conflict situation; cooperative situation.

\section{Introduction}

This article addresses the problem of teaching turn-taking to distance language learners on the examples of multimodal modern English cinematic discourse. In business communication, turn-taking is viewed as a meta-discursive category, an integral part of discourse management and control.

The problem of turn-taking as one of the most important properties of the structural organisation of oral interaction has drawn attention of different scholars. Equally, turn-taking is highly relevant for ESP and EFL teaching and learning (Jung, 2009; Saputro, 2015). In sociolinguistics, the procedure of turn-taking is viewed as accompanying structural and functional characteristic of social interaction (Gumperz, 1971; Mapes, 2018). In conversational analysis turn-taking is studied in terms of turns which consist of separate moves (Sinclair, Coulthard, 1992), the system of rules regulating speakers' turns in real time has been described.

In linguistic pragmatics, turn-taking is identified as a conversational strategy (van Dijk, 2015), a local operational apparatus of step-by-step turn-yielding, attempt-suppressing and turn-claiming in the process of speech bilateral interaction.

In communicative-discursive studies, turn-taking is considered to be the basic factor of the dynamic organisation of discourse (Makarov, 2003). The nature of turn-taking is considered to be dialogic, and turntaking strategies in German fiction are specified (Aristov \& Susov, 1999). Turn-taking is treated as a structure-organising discourse category (Karasik, 2004) or a meta-discursive operational category (Lavrinenko, 2011; Shevchenko, 2015).

In modern linguistics, the interest to the new object of analysis - cinematic discourse stipulated further attention to heterogeneous means of turn-taking. Cinematic discourse is a multimodal phenomenon which uses heterogeneous semiotic resources. In the cinematic discourse, "...the syntactic, prosodic and gestural dimensions should not be viewed as separate modalities but rather as interweaving resources used simultaneously in accomplishing actions in real-time interaction" (Helasvuo, Endo, \& Kärkkäilen, 2018, p.119). Its linguistic code is accompanied by non-linguistic and specific cinematic codes (Bateman, Schmidt, 2012; Virkkula-Räisänen, 2010), which opens up new possibilities of analysing the regulatory potential and multimodal resources (Cienki, 2016) for turn-taking in discourse (Mondada, 2007). In particular, on-screen turn-taking procedures can now be investigated as a result of intersubjectivity defined by Zlatev (2008b) as

Lavrinenko, I. \& Shevchenko, I. (2019). Turn-taking in cinematic discourse: linguistic characteristics and practical implications for ESP teaching. Advanced Education, 12, 55-63. DOI: 10.20535/2410-8286.155922 
"the sharing of states and processes of consciousness between two or more subjects" or "perceptual intersubjectivity" more commonly known under the label "joint attention" (p. 117). According to Zlatev (2008a), speaker-hearer joint attention and communicative intentions are both intersubjectivity skills (p. 232), though the intersubjective characteristics of turn-taking in the multimodal cinematic discourse still need a detailed analysis.

In teaching methodology, communicative competence which consists of linguistic, sociolinguistic, discursive and strategic components is an integral part of linguistic education. Turn-taking is a highly contextual element of communicative competence. It explains why ESP students should be aware that in speech their contributions are both context-shaped and context-renewing: as Seedhouse (2005) puts it, on the one hand, they cannot be adequately understood except by reference to the on-going sequential environment, and on the other, they inevitably form the further sequential environment (Seedhouse, 2005, p. 166).

In developing communicative competence for ESP students, traditional paradigms face a crucial shift towards distance learning. In the $21^{\text {st }}$ century, emerging paradigms of distance learning focusing on learning as a social process and supported by information and communication technologies are mainly the domain of sciences and IT-education. The history, methodology and practical issues of distance learning (Holmberg, 1995; Niess \& Gillow-Wiles, 2013) are widely discussed. But in language distance learning, its various formats are mainly used to teach grammar and lexis (White, 2014). In computer-mediated education on the whole, and in distance language learning, in particular, communicative skills are so far underestimated and deserve more attention in asynchronous (Swan et al., 2006) and in blended (Vaughan \& Norman, 2010) teaching models.

To breach this gap in this study we aim to reach both theoretical and practical objectives. Theoretically, we are going to lay the ground for the use of distance learning methodology to teach communicative competence, and to clarify the categorical nature of turn-taking; and practically, to sum up preliminary data of our analysis of teaching turn-taking skills, and to specify different semiotic resources of turn-taking in official situation of business communication, outline the parameters which affect their choice, and identify intersubjectivity markers of turn-taking in business situations in English cinematic discourse and discuss experimental distance learning results.

The object of our study is a meta-discursive category of turn-taking in the modern cinematic discourse as material for distance ESP learning.

In this article, we first provide an overview of linguistic material and methodological issues of its teaching. We further discuss in detail a meta-discursive category of turn-taking which is a component of communicative competence for ESP students. Finally, we outline the benefits of distance learning and its optimal formats to master turn-taking and related issues of communicative competence in ESP.

\section{Data and Methods}

The project of ESP distance learning initiated in V.N. Karazin Kharkiv National University gave rise to a thorough investigation into the issues of communicative competence in professional foreign language interaction. This investigation demands, on the one hand, a linguistic insight into turn-taking speech strategies; and, on the other, evaluation of teaching methodology best suitable for this aim. In this study, our analysis of tools and methods of teaching turn-taking is based on the experimental research in traditional and multimedia formats.

Research participants were 92 master students with B2 level of ESP majoring in International Economics and International Economic Relations in V.N. Karazin Kharkiv National University in 2016-17 and 2017-18 academic years. They were equally divided into experimental and control groups.

Research material was initially drawn from feature films. Their dialogues give ESP students the most adequate and concise picture of natural interaction, both verbal and prosodic as well as kinetic. On the whole, the material consisted of (1) short videos - episodes of business conversation from modern English cinematic discourse; (2) methodological materials explaining the principles of turn-taking in official English, and setting tasks for students' interactive activities aimed at developing their communicative skills; and (3) a self-assessment questionnaire.

Research procedure comprised general and particular methods. In experimental and control groups, multimedia (video) and traditional (oral explanation with text analysis) methods were used to teach students turn-taking strategies in official English. In the experimental group, interactive exercises, both online and inclass, were video-based, oral, both imitative and creative. In the control group, students had traditional tasks of making oral dialogues at their lessons based on written prompts and patterns. Linguistic tests measured experimental groups' proficiency in turn-taking strategies according to the Grading System in Ukraine ("A" $(90$ - 100) - Excellent, "B" (70 - 89) - Good, "C" (50 - 69) - Satisfactory, "E" (0 - 49) - Unsatisfactory). 
Before and after the experiment, students answered a number of questions to reveal their motivation, interest and results in learning the material as well as to estimate its accessibility and practical value for their future profession.

Linguistically, the analysis of turn-taking in discourse is theoretically underpinned by a functional anthropocentric approach which treats speech communication as an intended social activity (Leech \& Svartvick, 2003). In particular, we use the theory of linguistic conflict resolution (Frolova, 2009), argumentation theory (Eemeren \& Grootendorst, 1992), discourse theory (van Dijk, 2015; Martynyuk, 2008; Shevchenko, 2017), linguistic pragmatics (Senft, 2014; Susov, 2009) as well as the results of conversational studies of turn-organisation (Sacks, Schegloff, \& Jefferson, 1974) and the theory of intersubjectivity (SheetsJohnstone, 2012; Zlatev, 2008a, 2008b).

Our linguistic argumentation builds on instances of turn-taking collected from business situations in modern English cinematic discourse (feature films) comprising 850 turns.

This study of functional and pragmatic properties of turn-taking required a complex of methods: we use induction and deduction to define its categorical properties; contextual and intention-oriented analysis to identify speaker's communicative intentions and situation parameters; our data of various means of turntaking are registered according to notation system TRUD (Makarov, 2003); we use elements of conversational and discursive analyses to identify strategies, tactics and heterogeneous semiotic resources for turn-taking.

\section{Results and Discussion}

Distance language learning suggests a broad choice of formats and methods to teach communicative competence. In the subsections below, we first summarise linguistic characteristics of turn-taking and highlight its properties relevant to students of oral business communication; then we turn to the use of these linguistic data in distance language learning. Film episodes of business negotiations, court procedures, diplomatic conferences and the like which relate to students' future professional activities serve reliable examples of turn-taking for ESP learners.

\section{Turn-taking as a meta-discursive category}

In modern communicative-discursive paradigm, turn-taking is understood as an obligatory regulatory element of dialogic discourse development. Turn-taking strategies refer to the conversational type of supportive speech strategies and carry out structural and organisational functions in discourse. According to Shevchenko (2017), "discourse is an integral phenomenon, a mental-and-communicative activity, a unity of the process and result. From the point of view of ecolinguistics, discourse generates social relations and at the same time is their product. Discourse is a multidimensional cognitive-communicative-linguistic gestalt system which is defined by three aspects: meaning-making, ideas and beliefs formation (a cognitive aspect), and participants interaction in particular social-cultural contexts / situations (a social-pragmatic aspect), and the use of signs, both linguistic and non-linguistic (a linguistic aspect)" (p. 11).

Turn-taking is an operational meta-discursive category which provides for discourse structuring and regulating by transferring speakership from one participant to another in real time, or by claiming the right for a speaker's turn by the hearer. The distinction between discursive (cognitive, communicative) and metadiscursive categories (Shevchenko, 2015) highlights the operational nature of turn-taking: "In contrast to the cognitive and communicative categories, meta-discursive categories reveal the plane of expression: discourse structure, organisation, development" (p. 30).

In this paper, we chose discourse turns as units of analysis. "The central units of language in interaction are turns, and the formulation of a turn is crucially affected by its position in a conversational sequence" (Helasvuo, Endo \& Kärkkäilen, 2017, p. 118). The turn-taking category is actualised by communicative moves within corresponding turns, i.e., by the minimal unilateral units within bilateral ones.

\section{Turn-taking strategies: parameters, semiotic resources, discourse types}

Turn-taking strategy is a mental-and-linguistic phenomenon aimed at regulating participants' relations and discourse progression. As Frolova (2009) claims, the discourse strategy purports to achieve extralinguistic aims by drawing on mutual strategical knowledge which is realised in specific contexts, actualised in speech and duly interpreted by communicants. According to the basic meta-discursive goals, three strategies of turn-taking are identified: turn-claiming, attempt-suppressing and turn-yielding which are classified into initial and responding ones. Turn-taking strategies are actualised through particular tactics and their corresponding implementing techniques.

Various discursive parameters of turn-taking include speaker - addressee relations, their intentions, situations, etc. The parameter of adjoining turn correlation serves to distinguish between smooth turn-taking, 
turn-taking with interruption and turn-taking after a pause. The parameter of location serves to single out turn-taking potential / relevant / disagreement transition point.

On the assumption of the turn-recipient parameter three types of turn-taking are identified:

- addressee turn-yielding which is a direct (explicit) or indirect (implicit) appointment of the next speaker in the relevant transition point;

- multi-addressee turn-yielding which takes place when the speaker yields his current speaker's turn without pointing the addressee; in such cases of more than two participants, the choice of the next speaker is theirs.

The multimodal cinematic discourse is an integrity of heterogeneous semiotic resources, both linguistic and non-linguistic (prosodic, kinetic, proxemic), and cinematic codes which comprise a shot, cinematic phrase, narration, plot, montage, perspective, light, as well as music and noise (Bateman \& Schmidt, 2012). For language learners, these properties make cinematic discourse a veritable source of information about turn-taking in real conversation.

Depending upon the parameter of the global intention turn-taking strategies are divided into two groups: turn-taking in cooperative / confrontation discourse.

\section{Turn-taking in cooperative situations of business discourse}

In official situations of cooperative discourse, where local intentions of turn-taking combine with global cooperative intentions, turn-taking mostly occurs in relevant transition point and leads to harmonic communicative results. Depending on the level of cooperation in such situations, cooperative, correcting or competing responsive moves dominate. Participants' wants to preserve each other's faces result in dominant smooth turn-yielding and turn-claiming, while interrupting, and turn-taking after a pause are rather rare.

The choice of turn-taking is influenced by the participants' psychological and social parameters. In our data, participants with a lower social status prefer turn-taking tactics of statement / clarification, agreement / disagreement, and techniques of picking up and repetition. Participants with a higher status prefer tactics of statement / clarification, interrogation, agreement, doubt, order, and techniques of interrupting or topicswitching. For example, in a conversation with his assistant, the head of the company (Parrish) uses initiating turn-taking strategy, tactics of clarification (1468), and a repetition technique (1469):

PARRISH 1465: Good morning, Jennifer.

JENNIFER 1466: @ coming up to Parrish, hands over documents@ Good morning, Mr. Parrish.

JENNIFER 1467: @smiles@The Board iswaiting.

PARRISH 1468: @ takes documents, looksup indismay@What?

PARRISH 1469: @looks through documents@The board?

JENNIFER 1470: Did ${ }^{\text {not }}$ you call a Board meeting?

PARRISH 1471: @looks at his companions@ No [Meet Joe Black]

It is argued that "Conventionally, interruption has been conceptualised and studied as turn-taking violation, when one party starts talking before another has finished what they were saying" (Weatherall, Edmonds, 2018, p. 21). In the episode above, the violation of intersubjectivity principle is marked by topicswitching and intensified by a kinetic resource (a gesture).

In official discourse, participants reveal their dominance in conversations both linguistically and/ or non-linguistically, though the latter (kinetic and prosodic means) are more frequent.

In the female business discourse in comparison to the male one, the level of cooperation, as a rule, is higher. Turn-taking is realised by tactics of interrogation, agreement, and by phatic techniques. In the example below, Jennifer, an assistant, talks to her boss. She takes the speaker's turns using the tactics of interrogation $(808)$ and agreement $(810 ; 811)$. Parrish takes turns by the tactics of order $(807)$, and reproach (809). Intersubjective markers of relevant transition points are kinetic (look, gesture) and cinematic (medium shot):

PARRISH 807: And call my family, ${ }^{\text {would }}$ like them to come over for dinner tonight.

JENNIFER 808: Did ${ }^{\text {not }}$ the family get together last night?

PARRISH 809: @turns to her@ Jennifer-

JENNIFER 810: @nods@Of course,Mr.Parrish.

811: Right away. [Meet Joe Black]

In cooperative situations of professional business discourse, initiating strategies of turn-claiming are mostly actualised by tactics of statement, and responding strategies by tactics of agreement / disagreement. Their corresponding tactics are actualised by techniques of repetition, topic-switching, interrupting, picking up. In some cases, the turn-claiming strategy is also actualised by phatic means aimed at contact-making (tactics of attention-drawing). 
Turn-yielding strategies are mostly actualised by initiating tactics of interrogation or contact-making, and responding tactics of comment or move prolongation order. Turn-yielding strategy and its tactics are actualised by phatic techniques of initiating, supporting and breaking speech contact.

In cooperative situations of business discourse, attempt-suppressing strategy permits the speaker to continue his speech. It occurs in two types: initiating strategy of attempt-suppressing actualised by tactics of statement, and responding strategy of attempt-suppressing actualised by tactics of agreement / disagreement, and in some cases with tactics of doubt.

\section{Turn-taking in confrontation situations of business discourse}

Confrontation situations of business cinematic discourse are characterised by breaking harmony in interpersonal relations; the global intention is a conflict of participants' communicative goals. Under the conflict of goals, turn-taking is mostly realised by strategies which are aimed at participants struggle for speakership and which determine the choice of turn-taking tactics and techniques.

Turn-taking strategies depend on the level of confrontation. In situations with the maximal level, turntaking is actualised by tactics of offence, order, rude inducement, by interrupting and topic-switching techniques. Since participants do not aim to receive information, their turn-taking becomes unregulated, chaotic, and overlapping.

In situations with the minimal confrontation level, turn-taking is performed by tactics of offence, mockery, negative assessment; interrupting and topic-switching techniques dominate.

In conflict official situations, the choice of turn-taking types and means largely depends on social parameters: in the interaction of socially symmetric and asymmetric participants smooth turn-taking dominates; interruptive turn-taking dominates in the interaction of socially asymmetric participants; and turn-taking after a pause only occurs in the interaction of socially symmetric participants. The social parameter can intensify / neutralise discursive conflict. Turn-taking is often marked (intensified) by linguistic resources (invectives, question-question responses), and by non-linguistic markers, both kinesics, proxemics, and prosodic: gestures, speaker - hearer distancing, abrupt change of intonation, threatening silence etc.

Certain sets of turn-taking strategies, tactics and techniques correspond to each stage of conflict situation development. At the beginning stage or the stage of outright conflict, turn-taking is mainly performed by offence, mockery, emotional release, order, disagreement, by interrupting and topic-switching techniques. At the stage of conflict settlement, tactics of correction and agreement, and topic-switching technique dominate. For example, initiative move of Drew, a member of the board, actualises initiating a strategy of turn-claiming, tactics of statement $(1516 ; 1517 ; 1519)$. It is potentially troublesome for Parrish and meant to offend him and deprive him of his power. Parrish, the head and founder of the corporation, makes a responsive move with tactics of statement (1518), technique of silence. Non-linguistic markers (intonation, mimics) signal turn-taking below:

DREW 1516: @close shot@ The motion is passed.

1517: We will of course delay the announcement, out of respect for our former Chairman, until after the celebration of his birthday this weekend.

PARRISH 1518: Thank you for allowing me to save face, Drew.

DREW 1519: @to the Board@ The other motion before us is the acceptance of John Bontecou's offer to merge this corporation with Bontecou International-

@music, everybodylooksatParrish@

PARRISH 1520: @Parrish nods, steps forward, smiles bitterly@ OK [Meet Joe Black]

In conflict situations of business discourse, turn-claiming strategies actualised by initiating tactics of statement, order, and responding tactics of agreement / disagreement prevail. In our data, tactics of emotional release, menace, offence, mockery, negative assessment are the least frequent. Attempt-suppressing strategy is far less frequent than turn-claiming. Initiating strategies of turn-yielding are mostly actualised by tactics of interrogation including prosodic means and silence. Repetition and interruption prove to be the most frequent turn-taking techniques.

\section{Turn-taking strategies in blended distance language learning}

Distance education is a high priority in modern Ukraine in accord with the country major line of development in the globalisation era. The National Doctrine on the $21^{\text {st }}$ Century Education Development promotes the effectiveness of IT-technologies for higher education.

Anderson and Dron (2011) argue, that distance education has evolved through at least three generations of pedagogy according to different technologies: a cognitivist-behaviourist generation based on mass media (print, $\mathrm{TV}$, radio) and corresponding to 'one-to-one communication'; a constructivist generation connected with audio, 
video, web conferencing and facilitating 'many-to-many communication', and a connectivist generation based on Web 2.0 and social networks. These theories each play an important role in language education since "the Web sites, books, tutorial materials, videos, and so on, from which a learner may learn, all work more or less effectively according to how well they enable the learner to gain knowledge" (p. 80-97).

In language education, the shift from the traditional direct teacher - student interaction or correspondence courses resulted in a turn to online education. As White (2012) puts it, the evolution of distance language education from "print-based correspondence courses came first with educational radio and broadcast television, then audio and videocassettes, and most recently computers with computer-mediated communication (CMC), interactive multimedia and Web-based video, audio, and multimedia". She highlights "the most significant limitations of distance language learning, namely the separation of teachers and learners", and believes that multimedia facilitates developing interactive competence in the target language.

Depending on the purpose and material of tuition, distance education has created a number of formats. In synchronous learning, students are all present at the same time and can interact with each other and their teachers during the lesson. Its typical forms are: Web conferencing, including webinars, educational TV, videoconferencing applying telephone, Skype, blogs and other technologies and tools. In asynchronous learning students follows the curriculum at their own pace and place and are able to get feedback about their writing before they submit it to a tutor as in mail communication, digital games, write sites of their universities, etc. Each learning format has its achievements and limitations, a different task design (White, 2014).

In the last decade, blended learning is getting popularity. Vaughan and Norman (2010) claim, that blended learning, or the use of Web-based technology in conjunction with face-to-face learning, is the product of deep integration of information technology and curriculum. This format advocates micro-courses meant to solve a single knowledge problem. Blended framework integrates continued instructor monitoring and distance mediation with traditional forms of face-to-face interaction and outcome control.

The literature on teaching turn-taking in ELT suggests some practical models on turn-taking-based L2 teaching (Saputro, 2015) though it is still scarce and mainly leaves behind methods of teaching. Instead, it concentrates on culturally bound and discourse-type specific linguistic tactics of turn-taking (Ibraheem, 2017); on the patterns of turn-taking in classroom discourse which vary according to different participation frameworks (Jung, 2009); on models of speaker-hearer turn-taking awareness (Huges, 2006) and the like.

As an attempt to address the increasing demand of distance language education, V.N. Karazin Kharkiv National University has adopted a multi-level course project in ESP. At present, the creation of a number of courses is in progress. The first distance course (A2/B1 level) for students majoring in economics by Lavrinenko (certified in 2017) includes two blocks of materials. The grammatical block covers the topics of grammar (tenses, voice, etc.). The lexical block includes six topics: Economic Resources, Demand and Supply, etc. Its implementation created necessary grounds to broaden the contents of education to issues of communicative competence and stipulated a research into teaching turn-taking in oral interaction.

The blended format of distance learning proved to be the most relevant for the purpose of teaching communicative competence. Our experimental research had three stages. At the first and final stages of taking a distance course in turn-taking, 46 ESP students of experimental and 46 of control groups answered pre- and post-course questions.

While doing the distance course, students of the experimental group fulfilled a number of tasks based on the video episodes of professional interaction from cinematic discourse limited to 6-7 minutes. In the blended format, ESP students received their tasks and instructions, took their outcome control in a traditional in-class format, while the bulk of turn-taking learning and practising was Web-based. Namely, before and after individually watching the video episode, learners defined the situation (negotiation, meeting of the board, etc.), participants' roles (in a company or courtroom) and their relations, the topic of their discussion, its tone (cooperative / conflict) and estimated the efficiency of on-screen professional interaction. After watching the episode, they performed standard methodological tasks of linguistic analysis of the episode. Then, their attention was drawn to linguistic and non-linguistic (prosody, mimics, gestures, etc.) resources for turn-taking. Finally, in a language face-to-face class students synthesised their knowledge of turn-taking principles and techniques and did tutor-guided creative exercises. The tests on turn-taking revealed that $94 \%$ of students of the experimental group coped with linguistic tasks, among them:

$-67 \%$ were able to adequately use turn-taking techniques (level grades A, B);

$-27 \%$ did significant mistakes (grade C).

Other $6 \%$ of the group were not adequate in the use of turn-taking tactics (grade $\mathrm{F}$ according to the Grading System in Ukraine).

After the experiment, students answered questions summed up in Table 1 below. Each question received the total of 46 answers listed in corresponding columns. 
Table 1.“Turn-taking for ESP distance students”. Pre- and post-course questionnaire

\begin{tabular}{|c|c|c|c|c|}
\hline & & \multicolumn{2}{|c|}{ Pre-course } & Post-course \\
\hline$Q \#$ & Question & Response & $\begin{array}{c}\text { Number of } \\
\text { answers }\end{array}$ & $\begin{array}{c}\text { Number of } \\
\text { answers }\end{array}$ \\
\hline \multirow{2}{*}{1} & \multirow{2}{*}{ What is your motivation? } & Personal interest & 16 & 26 \\
\hline & & Career demand & 30 & 20 \\
\hline \multirow{2}{*}{2} & \multirow{2}{*}{$\begin{array}{l}\text { Do you know the rules of } \\
\text { English turn-taking? }\end{array}$} & Yes & 5 & 36 \\
\hline & & No & 41 & 10 \\
\hline \multirow[b]{2}{*}{3} & \multirow[b]{2}{*}{$\begin{array}{l}\text { How does the course fit } \\
\text { with your study plan? }\end{array}$} & I doubt I need it & 40 & 5 \\
\hline & & $\begin{array}{c}\text { It broadens my } \\
\text { communicative proficiency }\end{array}$ & 6 & 41 \\
\hline \multirow{3}{*}{4} & \multirow{3}{*}{$\begin{array}{l}\text { How do you practice your } \\
\text { distance courses? }\end{array}$} & PC at home & 19 & 14 \\
\hline & & I-phone & 21 & 25 \\
\hline & & Library/internet-cafe & 6 & 7 \\
\hline \multirow{2}{*}{5} & \multirow{2}{*}{$\begin{array}{c}\text { Does it fit your academic } \\
\text { level? }\end{array}$} & Yes & - & 40 \\
\hline & & No & - & 6 \\
\hline \multirow{2}{*}{6} & \multirow{2}{*}{ Were the videos useful? } & Yes & - & 42 \\
\hline & & No & - & 3 \\
\hline \multirow{2}{*}{7} & \multirow{2}{*}{$\begin{array}{c}\text { Were the explanations } \\
\text { useful? }\end{array}$} & Yes & - & 35 \\
\hline & & No & - & 11 \\
\hline \multirow{2}{*}{8} & \multirow{2}{*}{$\begin{array}{l}\text { Were the exercises } \\
\text { useful? }\end{array}$} & Yes & - & 30 \\
\hline & & No & - & 16 \\
\hline \multirow{2}{*}{9} & \multirow{2}{*}{$\begin{array}{c}\text { Are you satisfied with } \\
\text { your skills in turn-taking? }\end{array}$} & Yes & 6 & 24 \\
\hline & & No & 40 & 22 \\
\hline \multirow{2}{*}{10} & \multirow{2}{*}{$\begin{array}{l}\text { How do you prefer to take } \\
\text { this course? }\end{array}$} & Distance format & 10 & 33 \\
\hline & & Traditional format & 36 & 13 \\
\hline \multirow{2}{*}{11} & \multirow{2}{*}{$\begin{array}{l}\text { How do you prefer to take } \\
\text { outcome control? }\end{array}$} & Distance format & 7 & 6 \\
\hline & & Traditional format & 39 & 40 \\
\hline \multirow{2}{*}{12} & \multirow{2}{*}{$\begin{array}{c}\text { Will it help in your } \\
\text { professional activities? }\end{array}$} & Yes & 15 & 39 \\
\hline & & No & 31 & 7 \\
\hline
\end{tabular}

The table shows that before doing the course, most students were unaware of turn-taking in English (Q2), but after doing the course the students found their academic level (Q5) and blended distance format (Q10, Q11) appropriate; the course useful both for their education (Q3) and for their future career (Q12), though before the experiment their answers were different. The questionnaire also proves their satisfaction with the course (Q6, Q7, Q8) through watching videos arose greater interest than other forms of work such as teacher's comments and exercises. One possible explanation lies in the high quality of films and actors.

The questionnaire also proves that the suggested distance learning format is well suited for the task of teaching turn-taking to B2 ESP students (Q10). First, the answers indicate that students are highly motivated, either by career demand or by personal interest (Q1) and mark the growth of the former in the course of the experiment. Second, the students find the course useful for their turn-taking skills (Q9) or at least stimulating their personal growth $(\mathrm{Q} 3)$.

However, the questionnaire did not make it possible to find out whether the students' quantitative preferences of I-phones as a means of doing this course is an indication of their free and voluntary choice or if it results from some technical difficulties. In methodological literature, this is a common problem for distance learning courses in ESP (Peters, 2014).

In the control group, curriculum tuition was synchronous (for a comprehensive account of teaching turntaking in the interaction of lecturers and students see (Santoso et al., 2017)). At their lessons, with the help of multimedia technologies, students solved tasks corresponding to those in the experimental group. At the end of this course, they provided the answers which were mostly compatible with those in the experimental group (they did not answer Q4, Q11). Unlike the experimental group, they preferred traditional formats of tuition (Q10), as it might have been expected. But the main difference was in the evaluation of this course for personal and career growth: if the experimental group estimated this course as useful (Q12), the control group answered in the negative (11 'Yes' / 33 'No'). Some students explained it by the fact that their ESP curriculum was too tight and turn-taking seemed unnecessary or extra knowledge for them; while in the 
experimental group, their positive answers result from preferable psychological conditions of blended distance learning giving options for place, time and pace of learning.

The comparison of turn-taking skills attainment reveals that experiment participants demonstrated higher proficiency in defining such parameters of the video episode as the situation type, participants' roles and relations, topics and tone of their interaction; they were much more detailed in describing linguistic and non-linguistic means of turn-taking. We explain their high level of proficiency by no time limits given by the Web-based course format.

On the whole, this research proved that blended distance education is most suited for language learning. Along with its advantages, it revealed its limitations mainly grounded on users' technical restrictions and tutors' and administration attachment to traditional teaching frameworks.

\section{Conclusions}

The mixed methodological and linguistic analysis of turn-taking in a blended distance learning perspective has revealed that turn-taking is a meta-discursive category and an integral component of communicative competence in ESP. In official business situations of English multimodal cinematic discourse, complexes of turn-taking strategies and tactics, as well as linguistic, non-linguistic and cinematic means of their actualisation have been identified. Turn-taking regulates dialogic communication and serves as a precondition for effective professional discourse development.

From linguistic point of view, turn-taking is an aspect of the overall sequential organisation of talk. This study offers some theoretic solutions to the current problems of operational meta-discursive categories. Intersubjectivity explains for most cases of smooth turn-taking, while the lack of joint attention explains for the interruption as turn-taking violation. Turn-taking in cooperative and confrontation official business situations reveal clear instances of heterogeneous turn-taking resources serving as intersubjective triggers of speakership transfer. The system of turn-claiming, attempt-suppressing and turn-yielding tactics controls the process of dialogic interaction. The choice of turn-taking strategies and tactics is determined by the participant's local intentions, his/her social and psychological roles, and situational context.

From methodological point of view, turn-taking is an important aspect of ESP teaching. The data of our research experiment in creating a video-based blended distance learning mini-course outline the benefits and limitations of distance learning and prove that blending is the optimal format to master turn-taking. Currently, the results of our research experiment are used as a basis for the development of a blended distance mini-course in turn-taking and relevant meta-communicative skills for B2-level ESP students in V.N. Karazin Kharkiv National University. No doubt further work is needed to better understand the nature of communicative linguistic issues as well as methods and formats of distance language learning.

\section{References:}

Anderson, T., \& Dron, J. (2011). Three generations of distance education pedagogy. The International Review of Research in Open and Distance Learning, 12(3), 80-97. https://doi.org/10.19173/irrodl.v12i3.890

Aristov, A.A., \& Susov, I.P. (1999). Kommunikativno-kognitivnaya lingvistika i razgovorniy diskurs [Communicative cognitive linguistics and spoken discourse]. Lingvisticheskiy vestnik: sbornik nauchniyh trudov, 1, 5-10.

Bateman, J.A., \& Schmidt, K.-H. (2012). Multimodal film analysis: how films mean. New York, London: Routledge.

Cienki, A. (2016). Cognitive Linguistics, gesture studies, and multimodal communication. Cognitive Linguistics, 27(4), 603-618. https://doi.org/10.1515/cog-2016-0063

Dijk, T.A. van. (2015). Critical Discourse Analysis (new version). In D. Tannen, H. Hamilton, \& D. Schiffrin (Eds.), Handbook of Discourse Analysis. Vol. 1. (pp. 466-485). Chichester: Wiley Blackwell.

Eemeren, F. van., \& Grootendorst, R. (1992). Argumentaciya, kommunikaciya i oshibki [Argumentation, communication and mistakes]. St. Petersburg: Vasil'evskij ostrov.

Frolova, I.Y. (2009). Strategiya konfrontaciyi v anglomovnomu dyskursi [Strategy of confrontation in English discourse]. Kharkiv, Ukraine: Kharkiv Univ. Press.

Gumperz, J.J. (1971). Language in Social Groups. Stanford : Stanford University Press.

Helasvuo, M.-L., Endo, T. \& Kärkkäilen, E. (2018). Introduction. Units in responsive turns. Journal of Pragmatics, 123, 117-120. https://doi.org/10.1016/j.pragma.2017.07.006

Holmberg, B. (1995). Theory and Practice of Distance Education (Routledge Studies in Distance Education). 2nd Edition. New York: Routledge

Hughes, R. (2006). Turn-taking awareness: Benefits for teaching speaking skills in academic and other contexts. In Usó-Juan Esther, Martínez-Flor Alicia (Eds.), Current Trends in the Development and Teaching of the four Language Skills (pp.215-234). https://doi.org/10.1515/9783110197778.3.215

Hymes, D.H. (1972). On communicative competence. In J.B. Pride \& J.Holmes (Eds.), Sociolinguistics: selected readings (pp. 269293). Harmondsworth: Penguin.

Ibraheem, S.J. (2017). Turn-taking strategies in English language teaching (ELT). In Dr. Hussein Salem Mcawn (Ed.), Dirasat Tarbawiya (pp.291-308). Retrieved 7 May 2019 from https://www.iasj.net/iasj?func=fulltext\&aId=135181

Jung, E. H. (2009). The Machinery of Turn-taking in L2 Instructed Talk-in-interaction. English Language Teaching, 21( 3), 1-20.

Karasik, V.I. (2004). Yazykovoj krug: lichnost', koncepty, diskurs [Language circle: personality, concepts, discourse]. Volgograd: Peremena. 
Lavrinenko, I. (2011). Stratehii i taktyky zminy komunikatyvnykh rolei u suchasnomu anhlomovnomu kinodyskursi. [Turn-taking strategies and tactics in the contemporary English cinema discourse. Thesis for a PhD degree in philology, V. N. Karazin Kharkiv National university, Kharkiv, Ukraine.

Leech, G. \& Svartvik, J. (2003). A Communicative Grammar of English, Third Edition. N.Y.: Routledge.

Makarov, M.L. (2003). Osnovy teorii diskursa [Foundations of the discourse theory]. Moscow: Gnosis.

Mapes, G. (2018) (De)constructing distinction: Class inequality and elite authenticity in mediatized food discourse. Journal of Sociolinguistics, 22 (3), 265-287. https://doi.org/10.1111/josl.12285

Martynyuk, A.P. (2008). Regulyatyvna funkciya movy kriz pryzmu integratyvnyh tendencij u movoznavstvi [Regulative function of language through the prism of integrative trends of language studies]. Visnyk Kharkiv. nats. un-tu im.V.N. Karazina, 805, $10-15$.

Mondada, L. (2007). Multimodal resources for turn-taking: Pointing and the emergence of possible next speakers. Discourse Studies, 9, 194-225. https://doi.org/10.1177/1461445607075346

Niess, M., \& Gillow-Wiles, H. (2013). Developing Asynchronous Online Courses: Key Instructional Strategies in a Social Metacognitive Constructivist Learning Trajectory. The Journal of Distance Education, 27, (1). Retrieved from https://web.archive.org/web/20130820130944/http://www.jofde.ca/index.php/jde/article/view/831/1473

Peters, H. (2014). Global English online: A case study of a distance learning course in a business context. Language and Literacy, 16(1), 111-138. https://doi.org/10.20360/G28300

Sacks, H., Schegloff, E.A. \& Jefferson, G. (1974). A simplest systematics for the organization of turn-taking for conversation. Language, 50 (4), 696-735. https://doi.org/10.2307/412243

Santoso, I., Syihabuddin, S., Azis, A. \& Lukmana, I. (2017). Turn-Taking in German as Foreign Language Classroom. In Fuad Abdul Hamid, Didi Sukyadi et al. (Eds.), The Tenth Conference on Applied Linguistics and The Second English Language Teaching and Technology Conference in collaboration with The First International Conference on Language, Literature, Culture, and Education - Volume 1: CONAPLIN and ICOLLITE (pp.689-694). Bandung, Indonesia. https://doi.org/10.5220/0007173306890694

Saputro, T. H. (2015) The Relevance of Turn-Taking to EFL Teaching and Learning: An Awarness Raising and Practice Model. Celtic: Celtic: A Journal of Culture, English Language Teaching, Literature \& Linguistics, 2 (3), 19-26. https://doi.org/10.22219/CELTICUMM.Vol2.No3.19-26

Seedhouse, P. (2005) Conversation Analysis and language learning. Language Teaching, 38 (04), $165-187$. https://doi.org/10.1017/S0261444805003010.

Senft, G. (2014). Understanding Pragmatics: an interdisciplinary approach to language use. New York: Routledge.

Sheets-Johnstone, M. (2012). Fundamental and inherently interrelated aspects of animation. In A. Foolen, U. Ludtke, T. Racine, \& J.Zlatev, (Eds.), Moving ourselves, moving others: Motion and emotion in intersubjectivity, consciousness and language (pp. 29-55). Amsterdam: John Benjamins.

Shevchenko, I. (2015). Discourse Categories: A Case for Metacommunication. In M. Wilson (Ed.), Proceedings of Academic Science: 11th International Scientific and Practical Conference (pp. 28- 33). Sheffield: Science and Education Ltd

Shevchenko, I. (2017). Vvedeniye [Introduction]. In: Y.Bondarenko, A.Martynyuk, I.Frolova, I.Shevchenko (Eds.), Kak narisovat' portret pticy: metodologiya kognitivno-kommunikativnogo analiza yazyka. [How to draw a portrait of a bird: Methodology of cognitive-communicative analysis of language] (pp. 8-12). Kharkiv: Kharkiv University Press.

Sinclair, J. \& Coulthard, M. (1992). Towards an analysis of discourse. In M. Coulthard (Ed.), Advances in Spoken Discourse Analysis (pp. 1-34). London; N. Y.: Longman.

Susov, I.P. (2009). Lingvisticheskaya pragmatika [Linguistic pragmatics]. Vinnytsia, Ukraine: Nova Knyga.

Swan, K., Shen, J., \& Hiltz, S. R. (2006). Assessment and collaboration in online learning. Journal of Asynchronous Learning Networks, 10(1), 45-62. https://doi.org/10.24059/olj.v10i1.1770

Vaughan, D.R., \& Norman, D. (2010). Blended Learning. In M.F. Cleveland-Innes and D.R. Garrison (Eds.), An Introduction to Distance Education: Understanding Teaching and Learning in a New Era (pp. 165-198). New York: Routledge.

Virkkula-Räisänen, T. (2010). Linguistic Repertoires and Semiotic Resources in Interaction: A Finnish Manager as a Mediator in a Multilingual Meeting. International Journal of Business Communication, 47 (4), 505-531. https://doi.org/10.1177/0021943610377315

Weatherall, A. \& Edmonds, D.M. (2018). Speakers formulating their talk as interruptive. Journal of Pragmatics, 123, 11-23. https://doi.org/10.1016/j.pragma.2017.11.008

White, C. (2012). Distance Language Learning. In C. A. Chapelle (Ed.), The Encyclopedia of Applied Linguistics. Wiley Online Library (Online service). https://doi.org/10.1002/9781405198431.wbeal0338

White, C. (2014). The distance learning of foreign languages: A research agenda. Language Teaching, 47(4), 538-553. https://doi.org/10.1017/S0261444814000196

Zlatev, J. (2008a). The Co-evolution of Intersubjectivity and Bodily Mimesis. In J. Zlatev, T. Racine, C. Sinha, \& E. Itkonen (Eds.), The Shared Mind: Perspectives on Intersubjectivity (pp. 215-244). Amsterdam: Benjamins.

Zlatev, J., Brinck, I. \& Andrén, M. (2008b). Stages in the Development of Perceptual Intersubjectivity. In F. Morganti, A. Carassa, \& G. Riva (Eds.), Enacting Intersubjectivity: A Cognitive and Social Perspective on the Study of Interactions (pp. 117-132). Amsterdam: IOS Press.

Jung, E.H. (2009). The Machinery of Turn-taking in L2 Instructed Talk-in-interaction. 영어교육연구 [English Education Research], 21, 3, 1-20. https://doi.org/10.17936/pkelt.2009.21.3.001 